\title{
Experimental Investigation of Non-composite and Composite Deck Bridges
}

\author{
Abhishek Sharma ${ }^{*}$ K. K. Pathak, P. K. Singh \\ Department of Civil Engineering, IITBHU, Varanasi, India
}

Received February 9, 2021; Revised April 6, 2021; Accepted April 23, 2021

\section{Cite This Paper in the following Citation Styles}

(a): [1] Abhishek Sharma, K. K. Pathak, P. K. Singh, "Experimental Investigation of Non-composite and Composite Deck Bridges," Civil Engineering and Architecture, Vol. 9, No. 3, pp. 770-777, 2021. DOI: 10.13189/cea.2021.090318.

(b): Abhishek Sharma, K. K. Pathak, P. K. Singh (2021). Experimental Investigation of Non-composite and Composite Deck Bridges. Civil Engineering and Architecture, 9(3), 770-777. DOI: 10.13189/cea.2021.090318.

Copyright $\mathrm{C} 2021$ by authors, all rights reserved. Authors agree that this article remains permanently open access under the terms of the Creative Commons Attribution License 4.0 International License

\begin{abstract}
Use of composite RCC deck over steel bridges has now significantly increased. The detailed experimental study was conducted to ascertain improvements due to composite RCC deck over non-composite bridge model. Deck type steel bridge models, with and without composite decks were tested in laboratory up to failure. The failure in non-composite model was observed due to buckling of top chord member at a stress of $234.6 \mathrm{~N} / \mathrm{mm}^{2}$, whereas for the model with composite deck it changed to rupture of the bottom chord in tension at a stress of $614.8 \mathrm{~N} / \mathrm{mm}^{2}$. Failure load and stiffness of the structure also increased significantly due to the composite action. Shear connectors designed as per IRC 22:2008 transferred the shear effectively and deck slab also participated in load sharing. Further, load sharing in the top chord compression member comprising the steel top chord, the concrete in the deck slab, and the reinforcing steel in it, was also explored. It is found that $72.0 \%$ of the composite top chord compressive force is taken by the $\mathrm{RCC}$ deck, and in the RCC deck $30.7 \%$ force is taken by the reinforcement. Strain variation in deck slab was also recorded using strain gauges. Strain in deck slab over top chord members was observed to be $54 \%$ more than the strain in the middle of the deck slab.
\end{abstract}

Keywords Composite, Load-Test, Shrinkage Strain, Buckling, Strength, Stiffness

\section{Introduction}

Due to flexibility in functionality, efficient use of construction materials and aesthetical appeal, the steel-concrete composite bridge is an attractive design solution [1]. The strength of RCC in composite deck is best utilized when it is made composite to the compression carrying members of the truss. Twelve simply supported composite steel truss bridges between spans of $21 \mathrm{~m}$ to 63 $\mathrm{m}$ were constructed in the Czech Republic in the last decade [2]. Apart from load sharing, composite decks also increase lateral stiffness of the structure, which renders these suitable for a number of different types of bridge systems including cable stayed bridges [3] Introduction of light weight concrete [4] and fiber reinforced composite [5] into deck slab construction can further yield to weight reduction of deck and more economical design of bridges.

Laboratory testing on composite deck systems and connecting mechanism dates backs to early 1980s. In 1981, a composite steel truss bridge model was load tested at the University of Alberta, Canada [6]. A. Barttland, and D. J. L. Kennedy also conducted detailed flexural test on two full-scale composite truss bridge models in the year of 1986 [7]. They reported that the composite trusses showed ductile behavior up to failure, as the composite truss design was based on the ultimate tensile strength of the bottom chord and, web members and shear connectors were designed to be adequately strong.

Design recommendations and specifications for composite open web steel joists (OWSJ) are given in Standard Specification for Composite Steel Joists [8]. The design guidelines given in Canadian [9] and American codes are confined to the composite truss system used in building structures. There are no particular recommendations for the design of composite truss bridges in Euro code 4 [10]. In IRC: 22 (2008) [11], Standard 
Specifications and Code of Practice for Road Bridges Section VI (Composite Construction), there are no provisions for the design of composite steel truss bridges or buildings

\section{Shrinkage Strain in Deck Slab}

In the deck type composite bridge construction, steel truss is first launched and then deck slab and SIDL are cast. After the hardening of the deck slab and SIDL, the bridge is open to traffic. Total shrinkage strain in M40 grade deck slab concrete is 0.0003 (Cl. 5.2.4.1: IS 1343 [12], $\mathrm{Cl}$ 6.2.4.1: IS 456 [13]). Due to shrinkage, micro-cracks develop in the deck slab concrete, and it may not take flexural compressive stress until the micro-cracks are closed under the live load flexural stresses.

Therefore, it is reasonable to assume that composite action between RCC deck and steel truss will not start until flexural compressive strain in the deck slab concrete exceeds 0.0003 .

STAAD.Pro v8i analysis of a $30 \mathrm{~m}$ span composite steel truss bridge across a stream on the left bank of Bhagirathi river at Kotibhel, Uttrakhand, India (figure 1), with 200 $\mathrm{mm}$ thick deck slab over it is carried out.

Deck slab stress contour was obtained from the analysis at full live load due to Class A loading moving symmetrically on the deck using STAAD. Pro v8i software.

The maximum compressive stress of $6.06 \mathrm{~N} / \mathrm{mm}^{2}$ occurred at the middle span of the bridge. The equivalent strain in the deck slab is 0.00019 . Therefore, it may be concluded that full composite action in the bridge may not take place even at full-service load condition.

\section{Bridge Model Design and Fabrication}

Composite and non-composite underslung steel bridge models based on actual bridge proportions were selected for the experimental studies. The dimensions and $3 \mathrm{D}$ view of the model is shown in figure 2. Equal loadings at the four joints of the bridge model were applied during the load tests.

The model configuration is kept such that, at the mid-span, the bottom chord tension and the top chord compression are equal under symmetric loading. Cross-section of the middle top and bottom chord square bar members is kept as $8.0 \mathrm{~mm} \times 8.0 \mathrm{~mm}$. Except these, all other members are made stronger, so that failure of the model is ensured either by buckling of the top chord or by rupture of the bottom chord.



Figure 1. Elevation of $30 \mathrm{~m}$ span bridge used for analysis
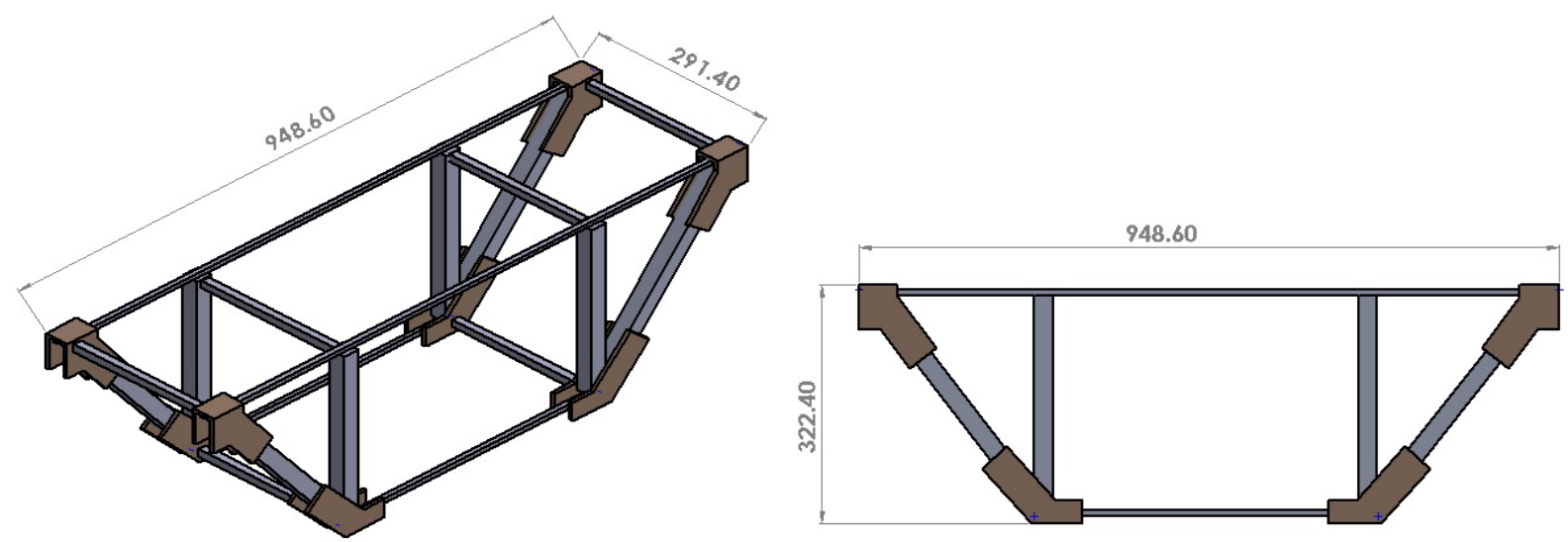

Figure 2. Model details 
Member forces in the model corresponding to the composite bridge model, under the four joint loads $\mathrm{P}$, are given in figure 3.

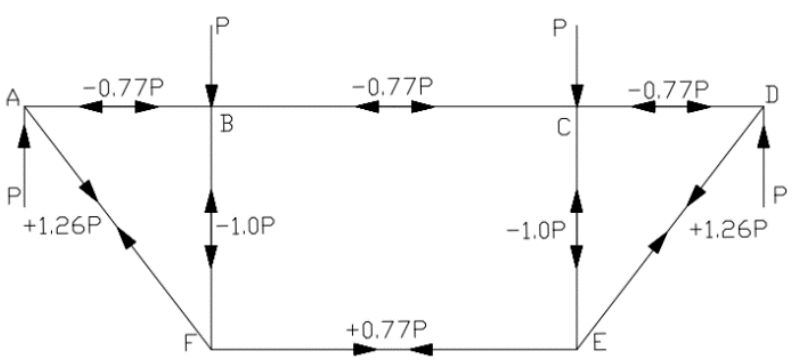

Figure 3. Member forces in the model

For the composite model, $20 \mathrm{~mm}$ thick RCC deck is made composite with the top chord members of the model using shear studs designed as per IRC 22:2008. Shear studs of $3.0 \mathrm{~mm}$ diameter and $18.0 \mathrm{~mm}$ height were welded over each top chord member at a spacing of 22.0 $\mathrm{mm} \mathrm{c/c}$ (figure 4).

Two layers of $3.0 \mathrm{~mm}$ dia. steel wire at a spacing of 60 $\mathrm{mm} \mathrm{c} / \mathrm{c}$ across the deck slab and $100 \mathrm{~mm} \mathrm{c} / \mathrm{c}$ along the deck slab were provided as the reinforcement in the deck slab (Figure 4).



Figure 4. Shear studs and deck reinforcement

\section{Material Test}

Materials used in the model fabrication were tested in the laboratory.

i. Tensile test of a square steel bar of size $8.0 \mathrm{~mm} \mathrm{x}$ $8.0 \mathrm{~mm}$.

The tensile test also included calibration of the electrical strain gauges used for measuring strains in the bridge models.

ii. Compression test of a standard specimen as per IS: 13780 [14] prepared from the steel bar used in the bridge model.

The sample for the compression test was prepared at 7/4 scale to the IS: 13780: 1993 specified scale. The obtained combined axial stress-strain curve for tension and compression is given in figure 5. As per IS 2062 [15], the steel was qualified for E600 grade, as its ultimate tensile strength was $734.0 \mathrm{~N} / \mathrm{mm}^{2}$ and percentage elongation was $15.1 \%$, against the specified corresponding values of $730.0 \mathrm{~N} / \mathrm{mm}^{2}$ and $12.0 \%$.

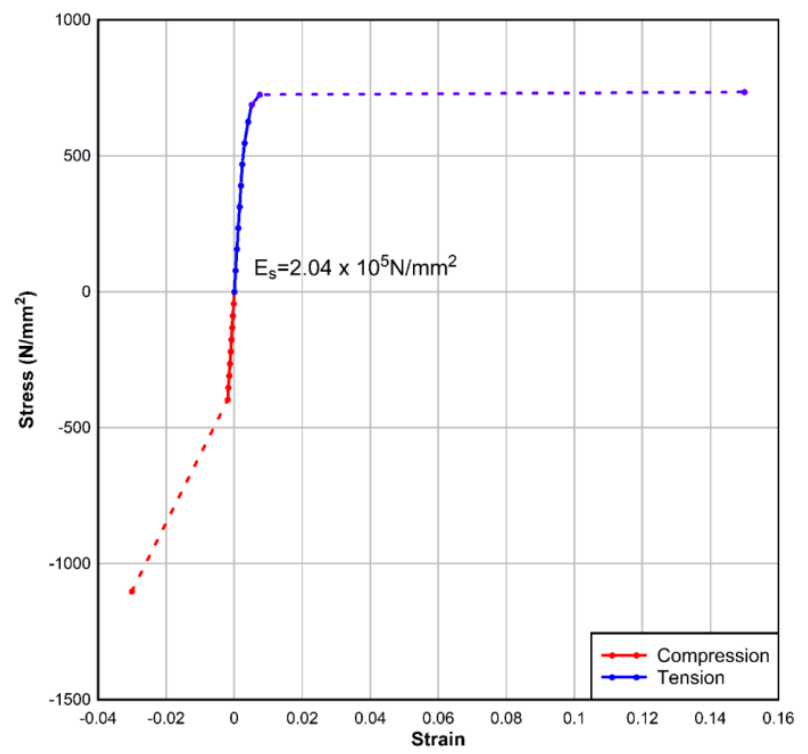

Figure 5. Combined stress-strain curve

RCC deck slab was prepared in 1: 1.5: 3 mix concrete using 43-grade PPC cement, sand having fineness modulus of 2.78 , and $5 \mathrm{~mm}$ aggregate. The water-cement ratio was kept as 0.4 . Sika viscockarete superplasticizer ( $1 \%$ by volume) was added. The average 2 - days cube compressive strength was found to be $58.2 \mathrm{~N} / \mathrm{mm}^{2}$

\section{Experimental Setup and Model Test}

The model and the composite bridge model were load tested on a $100 \mathrm{t}$ UTM (figure 6). In the model, four strain gauges were pasted on the middle top chord members to measure strain and two dial gauges at the bottom were used to measure deflection. In the composite bridge model test, thirteen strain gauges were used to record the strains, and two dial gauges were used to record the deflections.

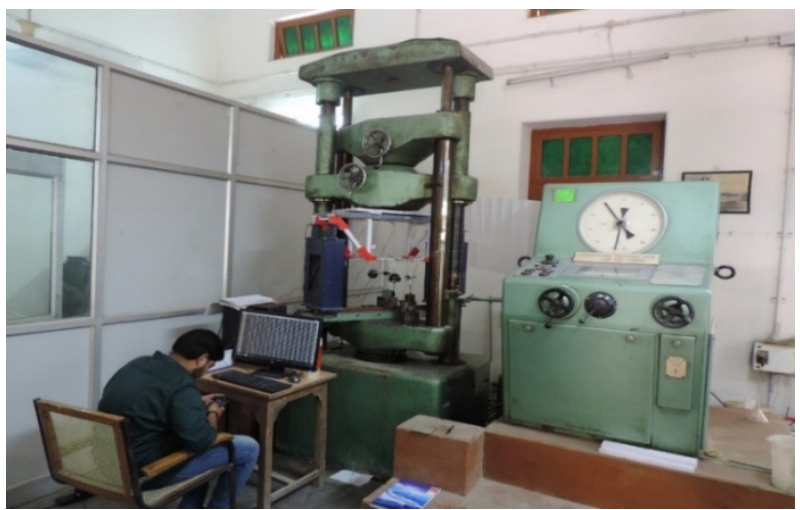

Figure 6. Experimental setup showing UTM, model, data logger and strain gauges

Mounting of the strain gauges on the steel members and the concrete deck slab are shown in figure 7. 

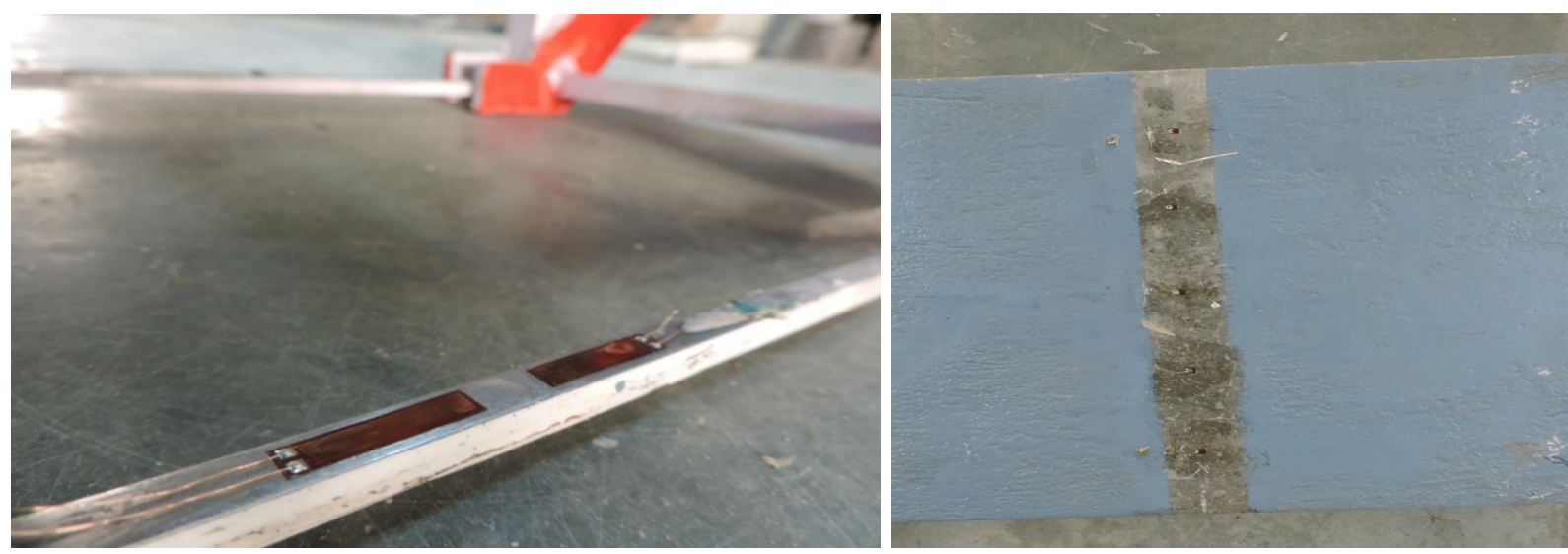

Figure 7. Strain gauge mounting (a) Two number on bottom chord, and (b) Five number on the deck slab
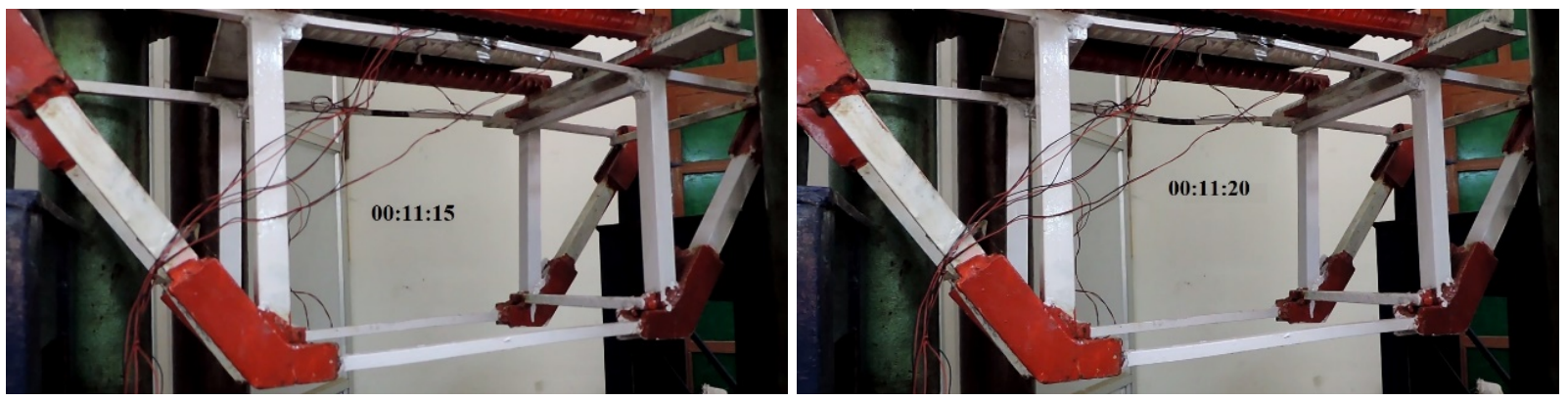

Figure 8. (a) Model before failure at 00:15:15Hrs, (b) Model after failure at 00:11:20 Hrs

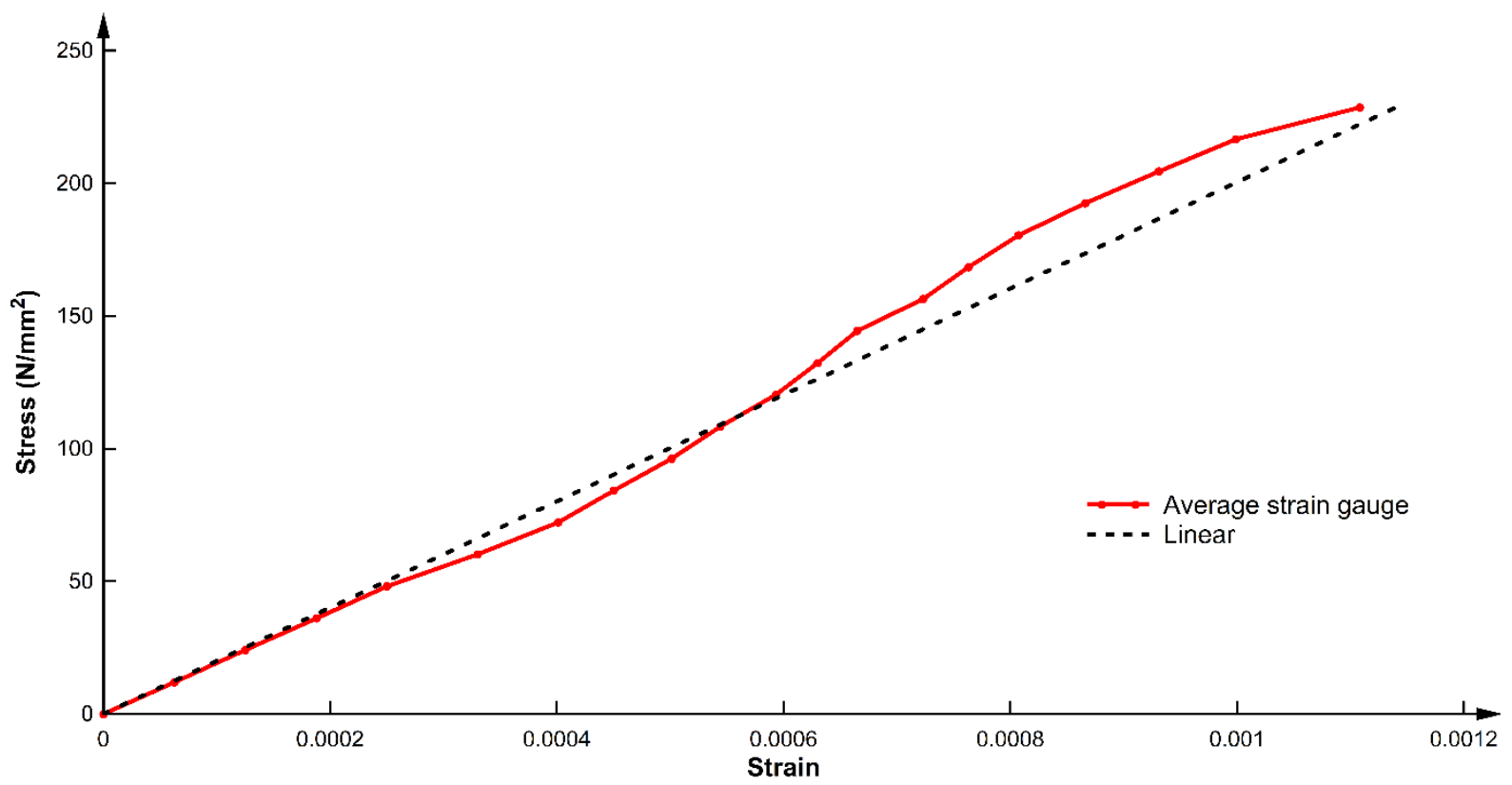

Figure 9. Average stress-strain curve for the non-composite model

\section{Test Results for the Non-composite Bridge Model}

The model failed due to the buckling of the two top chord members at a total load of $7.8 \mathrm{t}$, which corresponds to buckling stress of $234.6 \mathrm{~N} / \mathrm{mm}^{2}$. Figure 8 .a shows the model just before the buckling failure at 00:11:15 Hrs. and figure 8.b shows the failed model at 00:11:20 Hrs. from start of the model test.

The average stress-strain curve based on recorded strains from the four strain gauges pasted on top chord members is shown in figure 9.

The average load-deflection curve for the tested model is shown in figure 10 


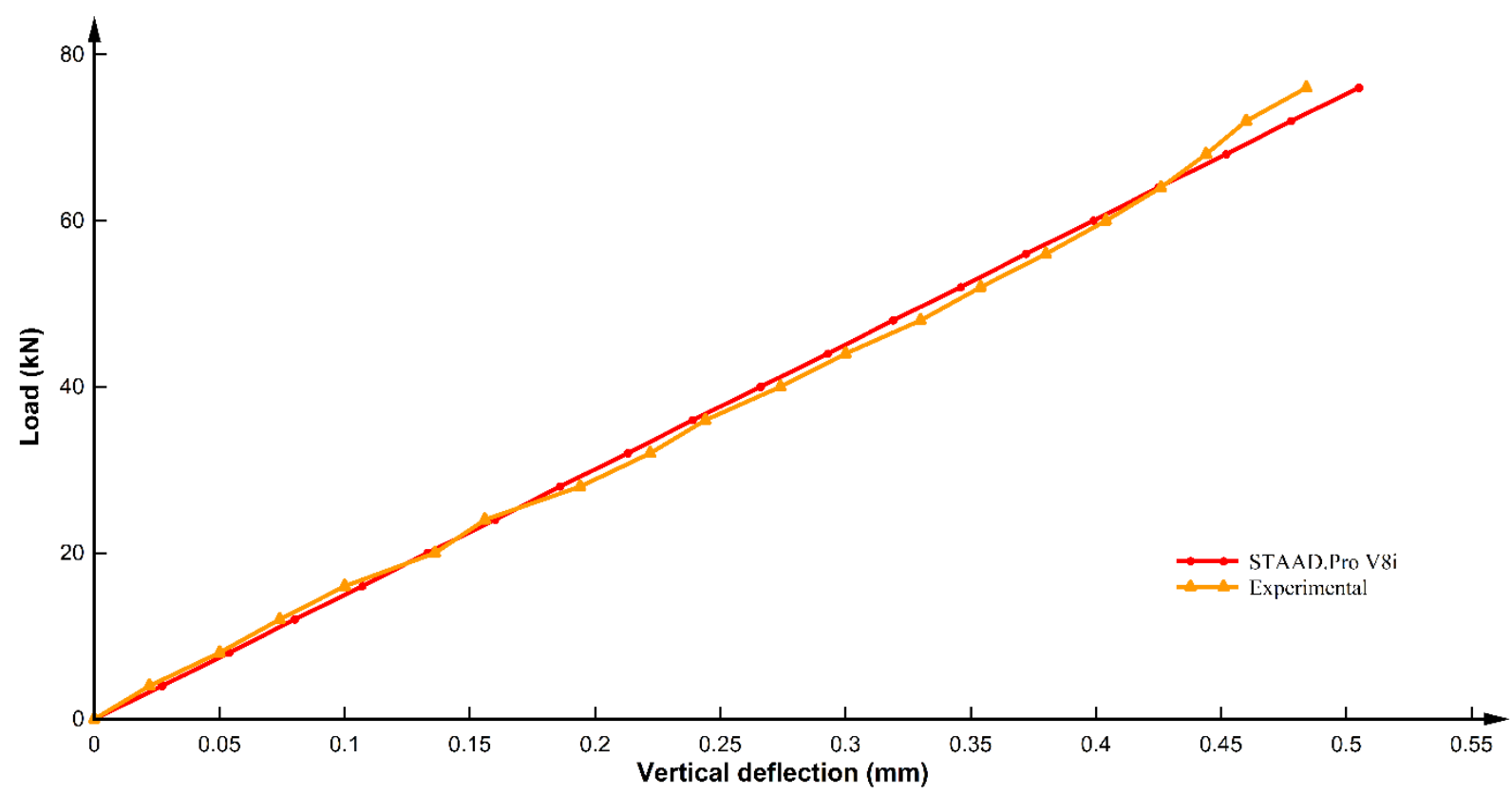

Figure 10. Average load-deflection curve for the non-composite model
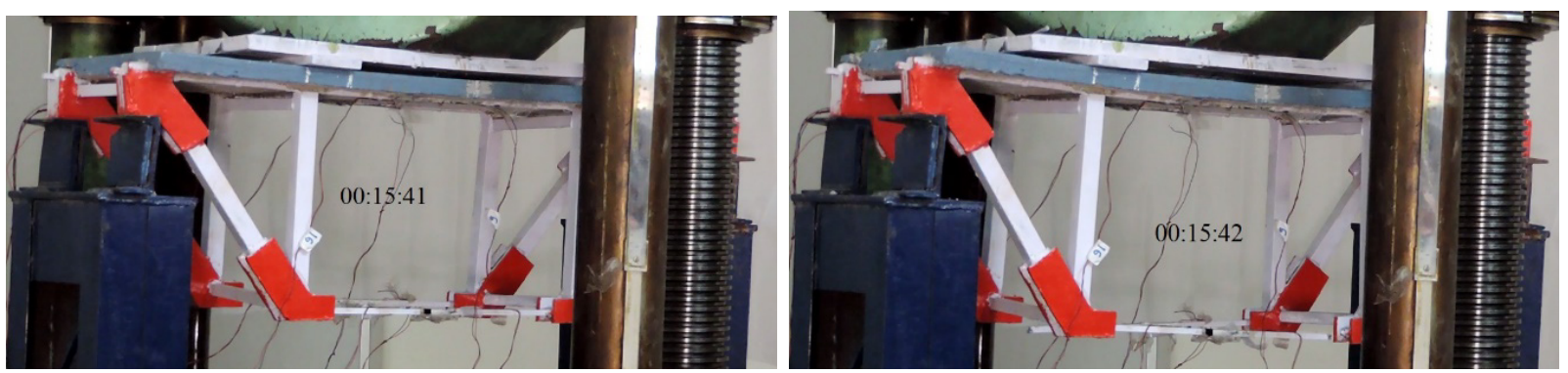

Figure 11. Composite model (a) before failure at 00:15:41 Hrs, (b) after failure at 00:15:42 $\mathrm{Hrs}$

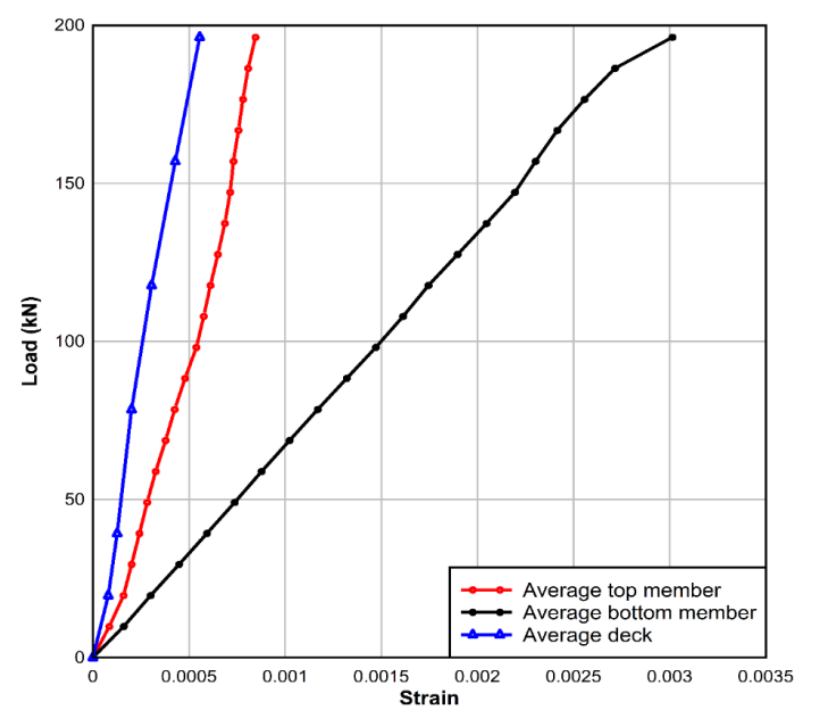

Figure 12. Load-strain curve for top chord, bottom chords and the deck slab

\section{Test Results for the Composite Bridge Model}

The composite bridge model failed due to the rupture of the two bottom chord members at a total load of $196.2 \mathrm{kN}$, which corresponds to a stress of $614.8 \mathrm{~N} / \mathrm{mm}^{2}$. Figure 11.a shows the model before failure at 00:15:41 Hrs, and figure 11.b shows its failure at 00:15:42 Hrs from start of the test.

Variations of the average recorded strains at the top chord, bottom chord and top of the deck slab are shown in figure 12 .

Load-deflection curve for the composite model is shown in figure 13.

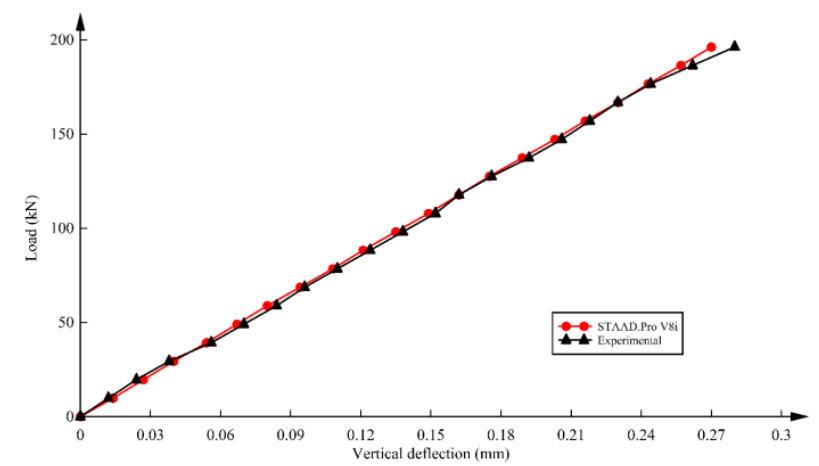

Figure 13. Load-deflection curve for the composite model 


\section{Test Results for the Composite Bridge Model}

Deflections of both the bridge models are approximately linear. The linear deflection of the composite bridge model indicates that shrinkage cracks in the deck slab have little effect on its load carrying capacity. At any load, the steel top chord member and the RCC deck slab share total compression in the composite top chord. Thus, any deficiency in the load sharing by the cracked RCC deck due to its shrinkage is adequately overcome by the steel top chord member.

\subsection{Load-Deflection Relationship}

Load deflection curves for the non-composite and the composite bridge models are approximately linear from the beginning up to failure. Deflection of the non-composite bridge model at failure load of $76.5 \mathrm{kN}$ is $0.48 \mathrm{~mm}$, and for the composite non-composite bridge model it is $0.27 \mathrm{~mm}$ at the failure load of $196.2 \mathrm{kN}$. Therefore, deflection at the ultimate failure for the composite bridge model is 0.56 times the deflection for the non-composite model.

Comparing deflections at the common load of $76.5 \mathrm{kN}$, at which the non-composite model failed, the ratio of deflections for the composite bridge model and the non-composite model is 0.21 .

\subsection{Load Carrying Capacity}

Ultimate load at failure for the non-composite bridge model is $76.5 \mathrm{kN}$ and for the composite bridge model, it is $196.2 \mathrm{kN}$. Therefore, the load-carrying capacity for the composite bridge is 2.56 times that of the non-composite bridge model.

\subsection{Stiffness}

Stiffness of the composite bridge is $727.4 \mathrm{kN} / \mathrm{mm}$ and for the non-composite, it is $166.3 \mathrm{kN} / \mathrm{mm}$. Therefore, stiffness of the composite bridge is 4.37 times stiffness of the corresponding non-composite bridge model, which may vary in the size of the deck slab in relation to the non-composite size.

\subsection{Model of Failure}

However, the non-composite bridge model failed due to the buckling of its top chord members at a load of $76.5 \mathrm{kN}$, the mode of failure for the composite bridge model entirely changed to rupture of the bottom chord members at a much higher load of $196.2 \mathrm{kN}$.

Buckling failure of a bridge is highly undesirable as it is sudden in nature. The composite bridge model gradually failed due to yielding and rupture of the bottom chord members at much higher stress of $614.8 \mathrm{~N} / \mathrm{mm}^{2}$ in comparison with buckling failure of top chord members at a stress of $234.6 \mathrm{~N} / \mathrm{mm}^{2}$. Thus, composite bridges may allow design with higher reserve strength.

\subsection{Load Sharing between Steel Top Chord and the RCC Deck Slab}

Both, the top chord as well as bottom chord members of the non-composite consist of $8 \mathrm{~mm} \times 8 \mathrm{~mm}$ square steel bars. Therefore, in the symmetrical non-composite bridge model force carried by the top chord and bottom chord members is equal. Similarly, in the case of the composite bridge model also, the tensile force carried by the bottom chord member must be equal to the compressive force carried by the top chord and the RCC deck jointly.

Member forces in the bottom chord and top chord are calculated from the respectively recorded strains. The deck slab compressive force is calculated as the difference between the top chord compressive force and bottom chord tensile force, which is shown in figure 14. The deck slab, including concrete and the reinforcing steel, takes up $72.0 \%$ of the total compression in the composite top chord.

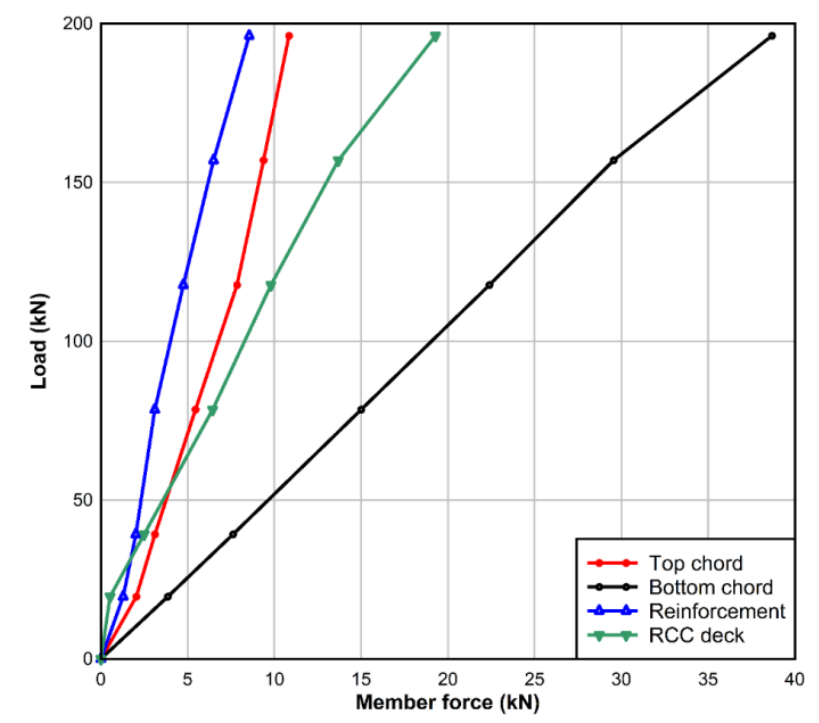

Figure 14. Load sharing between top chord, reinforcement and concrete deck

Assuming that the reinforcement has the same strain as the surrounding concrete in the deck slab, force taken by the cracked deck slab concrete is calculated as the difference between the total force taken by the two and the force taken by the reinforcement alone. Therefore, at the failure, $30.7 \%$ of the total RCC deck force is taken by the reinforcing steel.

\subsection{Strain in the Deck Slab}

The strain in the deck slab is recorded using five strain gauges mounted at $6.5 \mathrm{~cm}$ center to center from each other 
(figure 7.b).The strain profiles at different loading stages are shown in figure 15. The average strain in the deck slab at the failure load of $196.2 \mathrm{kN}$ is 0.000431 . This indicates that the deck slab at failure fully participates in the composite action.

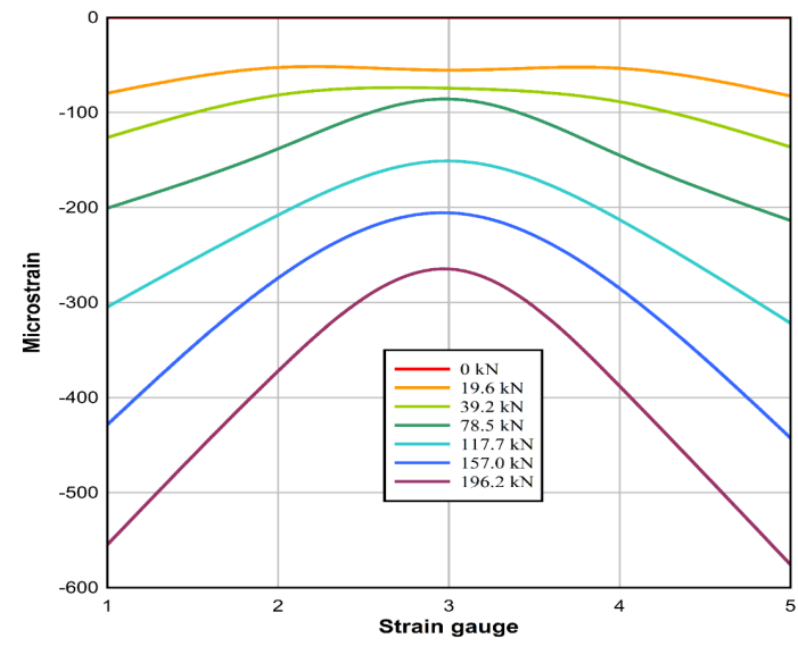

Figure 15. Deck slab strain profiles at different loadings

Strain in the deck slab significantly reduces from maximum strain at the top chord member locations from 0.00058 to minimum strain at the mid-section as 0.00026 , which is reduced by $54.0 \%$.

Deck slab top view after failure is shown in figure 16 . From the figure, it is clear that there is no adverse cracking or crushing of the deck slab at any location

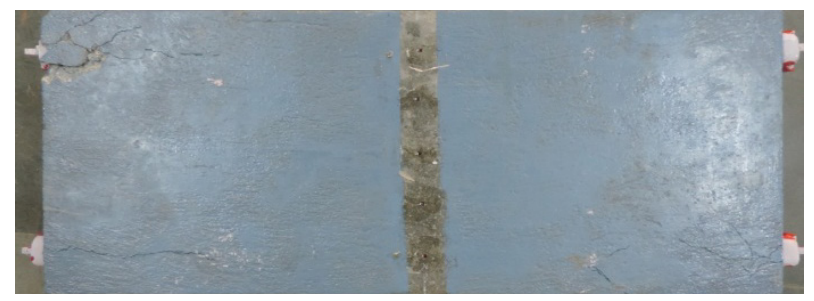

Figure 16. Deck slab top view after failure

\subsection{Performance of Shear Studs}

Shear studs designed as per IRC 22:2008 satisfactorily performed in the composite bridge model up to the failure load (figure16). Therefore, it may be inferred that equal spacing of the shear studs is adequate and concentration of shear studs at the joints may not be required. Equal spacing of the shear studs may also be justified due to the shrinkage cracking in the deck slab of the bridge.

\section{Conclusions}

In France and the Czech Republic, composite bridges for medium spans have been popularly built in the past. However, there are no specific codal provisions available for the design of the composite steel truss bridges. Shrinkage strain in the deck slab concrete also renders the composite action doubtful. Based on the experimental results and the discussions, the following conclusions are drawn.

1. Shrinkage strain in M40 deck slab concrete is of the order of 0.0003 . As per the STAAD analysis of the $30.0 \mathrm{~m}$ span composite bridge, the flexural strain for LL condition is 0.00019 . Therefore, it may be apprehended that even under full live load condition complete composite action may not take place. However, the linear load-deflection behavior of the composite model allays this fear.

2. At the common load of $76.5 \mathrm{kN}$, at which the non-composite model failed, the ratio of deflections for the composite bridge model and the non-composite model is 0.21 . Thus, composite bridge is preferable from the serviceability consideration.

3. Ultimate load at failure for the non-composite bridge model is $76.5 \mathrm{kN}$ and for the composite bridge model it is $196.2 \mathrm{kN}$. Therefore, the load carrying capacity for the composite bridge is 2.56 times that of the non-composite bridge model.

4. Stiffness of the non-composite model is found to be $166.3 \mathrm{kN} / \mathrm{mm}$, and for the composite bridge model it is $727.4 \mathrm{kN} / \mathrm{mm}$. Therefore, stiffness of the composite bridge is 4.37 times the stiffness of the non-composite bridge, which may vary in relative sizes of the deck slab and the steel members.

5. Mode of failure for the non-composite bridge model is sudden due to buckling of the top chord members at a stress of $234.6 \mathrm{~N} / \mathrm{mm}^{2}$. Failure mode for the composite bridge model is entirely changed to rupture of its bottom chord members at higher stress of $614.8 \mathrm{~N} / \mathrm{mm}^{2}$. Thus, composite bridge design may permit higher reserve strength in comparison to the non-composite bridge.

6. At the central section of the model, load sharing by the deck slab is $72.0 \%$ and the remaining $28.0 \%$ is taken by the top chord member. At the failure, $30.7 \%$ of the total RCC deck compressive force is taken by the reinforcing steel in it.

7. Due to load sharing by the RCC deck along with the load taken by the steel top-chord member, maximum stress in the top chord member is limited to 168.0 $\mathrm{N} / \mathrm{mm}^{2}$, which is lower than the top chord buckling stress of $234.6 \mathrm{~N} / \mathrm{mm}^{2}$. Therefore, the buckling of the top chord compression member is entirely eliminated in composite bridges.

8. Strain in the deck slab significantly reduces from the maximum strain at the top chord member location of 0.00058 to the minimum strain in the middle of the two frames to 0.00026 , which is reduced by $54.0 \%$. The average strain near failure at the top of the deck slab is 0.00043 .

9. Shear studs may be designed for ultimate load conditions due to the rupture of the central bottom 
chord members. Spacing of the shear studs may be kept equidistant from shrinkage crack consideration, and not concentrated over the joints.

From the experimental investigation, it is concluded that load carrying capacity of the composite bridge is enhanced by $156.0 \%$ and its stiffness increased by $337.0 \%$. Shrinkage cracking in the deck slab has little or no effect on the composite action and its load-deflection curve remains linear throughout. Out of the total compressive force carried by the composite top chord, $72.0 \%$ force is carried by the RCC deck. In the RCC deck, 30.7\% compressive force is carried by the reinforcing steel. Thus, the composite steel truss bridge offers a safe, economical and aesthetically appealing solution.

\section{REFERENCES}

[1] Reis. A., \& Oliveira Pedro, J. J. Composite truss bridges: new trends, design and research.Steel Construction, 4(3). 2011, 176-182. https://doi.org/10.1002/stco.201110024

[2] J. Machacek, M. Charvat. Design of Shear Connection between Steel Truss and Concrete Slab, 11th International Conference on Modern Building Materials, Structures and Techniques, MBMST 2013, Procedia Engineering, Elsevier, 57, pp. 722-729, 2013. DOI: 10.1016/j.proeng.2013.04.091.

[3] J.B.Marcussen. Design and construction in composite bridges", EUROSTEEL 2017, September 13-15, 2017, Copenhagen, Denmark.

[4] Fayez Moutassem, "Ultra-Lightweight EPS Concrete: Mixing Procedure and Predictive Models for Compressive Strength," Civil Engineering and Architecture, Vol. 8, No. 5, pp. 963 - 972, 2020. DOI: 10.13189/cea.2020.080523.
[5] Trong-Phuoc Huynh, Van-Hien Pham , Tri-Khang Lam , Nguyen-Trong Ho , "Experimental Research on the Performance of Polypropylene Fiber Foamed Ultra-lightweight Composites," Civil Engineering and Architecture, Vol. 8, No. 4, pp. 654 - 661, 2020. DOI: $10.13189 /$ cea.2020.080429.

[6] R. Bjorhovda, "Full-scale test of composite truss", Structural Engineering Report No. 97, Department of Civil Engineering, University of Alberta.

[7] A. Barttland, D. J. L. Kennedy, "Flexural tests of two full-scale composite trusses", Canadian Journal of Civil Engineering, 1992, 19(2): 279-295

[8] SJI-CJ-2010, American National Standard, "Standard Specification for Composite Steel Joists C-J series".

[9] Canadian Institute of Steel Construction (CISC), Handbook of Steel Construction, CAN/CSA S16.1 94, Section 16, Open-Web Steel Joists, 7th Edition, Willowdale, Ontario, 1997.

[10] ENV 1994-2. Eurocode-4: Design of composite steel and concrete structures, Part 2: Composite bridges. CEN; 2001.

[11] IRC: 22-2008, "Standard Specifications and Code of Practice for Road Bridges Section VI (Composite Construction)," Indian Road Congress, 1986, India.

[12] IS: 1343-2012, "Prestressed concrete- Code of practiceSection1: General, BIS, India.

[13] IS: 456-2008, "Standard Specifications and Code of Practice for Road Bridges Fourth revision,” BIS, India.

[14] IS: 13780: 1993, Indian Standard, "Hardmetals Compression test".

[15] IS 2062:2011, Indian Standard, "Hot rolled medium and high tensile structural steel - specification. 